\title{
ANALISIS PENGARUH CASH POSITION, DEBT TO EQUITY RATIO DAN RETURN ON ASSETS TERHADAP DIVIDEND PAYOUT RATIO PADA PERUSAHAAN MANUFAKTUR YANG TERDAFTAR DIBEI PERIODE 2013-2015
}

\author{
Noviarti ${ }^{1}$ \\ noviarti.arif@gmail.com
}

Putri Dwi Saprilyana ${ }^{2}$

Jurusan Manajemen, Fakultas Ekonomi, Universitas Satya Negara Indonesia Jalan Arteri Pondok Indah No.11 Jakarta Selatan

\begin{abstract}
The Purpose this research is to analyze the effect of Cash Position, Debt to Equity Ratio and Return On Assets of the Dividend Payout Ratio on Manufacturing companies listed on the Stock Exchange in the period 2013-2015. Testing the hypothesis in this study using multiple linear regression analysis. The population in this study are all manufacturing companies listed in Indonesia Stock Exchange (BEI) in the year 2013 to 2015 is 133 companies, while the sample is 43 companies with purposive sampling as the sampling technique. The results of this study prove that Cash Position, Debt to Equity Ratio and Return On Assets simultaneously affect the Dividend Payout Ratio, seen from the F test found significant levels of less than 0.05 is $0.000<0.05$. But only partially Debt to Equity Ratio which significantly influence Dividend Payout Ratio, seen from t test that only the Debt to Equity Ratio is smaller than the significance level of 0.05.
\end{abstract}

Keyword : Cash Position, Debt to Equityratio, Return on Assets and Dividend Payout Ratio

\section{PENDAHULUAN}

Brigham dan Houston (2009) menyatakan bahwa nilai perusahaan tidak ditentukan oleh besar kecilnya dividend payout ratio, tetapi ditentukan oleh kemampuan dasar perusahaan untuk menghasilkan laba, dan investor merasa lebih aman memperoleh pendapatan berupa dividen daripada capital gain serta menginginkan menerima dividen yang relatif stabil. Banyak faktor yang mempengaruhi kebijakan dividen seperti Cash Position, Return on assets, debt to equity ratio. Pada kenyataannya faktor-faktor tersebut tidak selalu mampu mempengaruhi kebijakan dividen seperti yang dijelaskan diatas secara teoritis dan terdapat fenomena yang terjadi berbanding terbalik dengan teori yang ada. Berikut salah satu fenomena yang terjadi dimana Cash Position, Debt to Equity Ratio dan Return on Assets tidak mampu mempengaruhi kebijakan dividen yang diukur dengan indikator Devidend Payout Ratio. 
Tabel 1

PT ASAHIMAS FLAT GLASS Tbk

\begin{tabular}{|l|r|r|r|r|}
\hline \multirow{2}{*}{ Variabel } & \multicolumn{4}{|c|}{ Tahun } \\
\cline { 2 - 5 } & 2010 & 2011 & 2012 & 2013 \\
\hline DPR \% & 10,49 & 10,30 & 10,02 & 10,26 \\
\hline CP \% & 1,6349 & 1,7414 & 1,8696 & 2,5465 \\
\hline DER \% & 0,2874 & 0,2542 & 0,2679 & 0,2821 \\
\hline ROA \% & 0,1395 & 0,1252 & 0,1113 & 0,0956 \\
\hline
\end{tabular}

Sumber: Diolah Penulis

Dari tabel diatas dapat diketahui bahwa pada tahun 2010 hingga tahun 2012 nilai Cash Position pada PT Asahimas Flat Glass mengalami kenaikan namun nilai Dividend Payout Ratio mengalami penurunan, hal ini bertentangan dengan teori yang sudah dijelaskan sebelumnya bahwa saat Cash Position turun maka Dividend Payour Ratio akan turun. Return on Assets pada PT Asahimas Flat Glass mengalami penurunan pada tahun 2012 menuju 2013 justru Dividend Payout Ratio pada perusahaan itu mengalami kenaikan, hal ini juga bertentangan dengan teori yang menjelaskan bahwa pada saat Return on Assets naik maka Devidend Payout Ratio akan berpotensi naik.

Dan saat Debt to Equity Ratio pada PT Asahimas Flat Glass mengalami penurunan pada tahun 2010 menuju 2011 justru Dividend Payout Ratio pada perusahaan itu mengalami penurunan juga dan pada tahun 2012 menuju 2013 Debt to Equity Ratio pada perusahaan itu mengalami kenaikan tetapi Dividend Payout Ratio justru mengalami kenaikan.

Penelitian sebelumnya yang terkait dividend payout ratio telah banyak dilakukan namun menunjukan hasil penelitian yang berbeda-beda. Berikut ini adalah penelitian sebelumnya yang terkait dengan faktor yang mempengaruhi dividend payout ratio dengan hasil yang berbeda.

\section{Tabel 1}

Research Gap

\begin{tabular}{|c|l|r|l|}
\hline Variabel & \multicolumn{1}{|c|}{ Peneliti } & Tahun & \multicolumn{1}{c|}{ Hasil Penelitian } \\
\hline \multirow{4}{*}{ CP } & Siti Nurjanah & 2013 & CP berpengaruh terhadap DPR \\
\cline { 2 - 5 } & Azhari & 2012 & CP berpengaruh terhadap DPR \\
\cline { 2 - 5 } & Esti Rudiana & 2016 & CP tidak berpengaruh terhadap DPR \\
\cline { 2 - 5 } & Gede Agus & 2014 & CP tidak berpengaruh terhadap DPR \\
\hline \multirow{3}{*}{ ROA } & Fenny Pramita & 2013 & ROA berpengaruh terhadap DPR \\
\cline { 2 - 5 } & Gede Agus & 2014 & ROA berpengaruh terhadap DPR \\
\cline { 2 - 5 } & Esti Rudiana & 2016 & ROA tidak berpengaruh terhadap DPR \\
\hline \multirow{3}{*}{ DER } & Gede Agus & 2014 & DER berpengaruh terhadap DPR \\
\cline { 2 - 5 } & Siti Nurjanah & 2013 & DER tidak berpengaruh terhadap DPR \\
\cline { 2 - 5 } & Esti Rudiana & 2016 & DER tidak berpengaruh terhadap DPR \\
\hline
\end{tabular}

Sumber: Diolah Penulis 
Berdasarkan penjelasan diatas dan masih adanya perbedaan hasil penelitian sebelumnya maka penelitian selanjutnya masih perlu dilakukan penelitian.

\section{KERANGKA PEMIKIRAN TEORITIS}

Kebijakan deviden merupakan bagian yang tidak dapat dipisahan dengan keputusan pendanaan perusahaan.Secara definisi Kebijakan Deviden adalah kebijakan untuk menentukan berapa laba yang harus dibayarkan (deviden) kepada pemegang saham dan berapa banyak yang harus ditanam kembali (laba ditahan).Deviden adalah pendapatan bagi pemegang saham yang dibayarkan setiap akhir periode sesuai dengan persentasenya. Persentase dari laba yang akan dibagikan sebagai deviden kepada pemegang saham disebut sebagai Deviden Payout Ratio (DPR).

Menurut Sutrisno $(2012 ; 266)$ pengertian kebijakan dividen adalah memutuskan apakah laba yang diperoleh oleh suatu perusahaan selama satu periode akan dibagi semua atau dibagi sebagian untuk dividend dan sebagian lagi tidak dibagi dalam bentuk ditahan.

Menurut Horne dan Wachowicz (2012:289-291), kebijakan dividen saham dibagi menjadi dua yaitu :

1. Dividen Saham (stock dividend), merupakan pembayaran berupa saham biasa tambahan kepada para pemegang saham, digunakan sebagai pengganti atau tambahan dari dividen tunai.

2. Pemecahan Saham (stock split), merupakan peningkatan jumlah saham yang beredar dengan mengurangi nilai nominal saham, contoh pemecahan saham dua untuk satu akan membuat nilai nominal per saham berkurang menjadi setengahnya.

\section{Teori kebijakan Dividen}

Menurut preferensi investor ada tiga teori yang mendasari kebijakan dividen (Brigham dan Houston 2011:211), yaitu :

1. Teori Dividen Tidak Relevan

Teori dividen tidak relevan dikemukakan oleh Merton Miller dan Franco Modigliani (MM).Teori ini menyatakan bahwa kebijakan dividen tidak berpengaruh pada harga saham maupun terhadap biaya modal perusahaan.Teori MM berpendapat bahwa nilai suatu perusahaan ditentukan pada kemampuan perusahaan dalam memperoleh laba, bukan pada bagaimana laba tersebut dibagi menjadi dividen dan laba ditahan.

2. Bird in the Hand Theory

Gordon dan Lintner berpendapat bahwa para investor lebih menyukai dividen dibandingkan dengan capital gain. Dividen memiliki risiko yang lebih rendah dibandingkan dengan capital gain, oleh karenanya investor akan merasa lebih aman untuk mengharapkan dividen saat ini dibandingkan menunggu capital gain yang di masa depan.

3. Tax Differential Theory

Teori ini didasarkan atas pada perbedaan pajak antara dividen dengan keuntungan modal (capital gain).Pajak atas dividen harus dibayarkan pada tahun saat dividen tersebut diterima, sedangkan pajak atas capital gain tidak dibayarkan sampai saham dijual.Adanya keunggulan pajak tersebut maka membuat investor lebih menyukai capital gain karena dapat menunda pembayaran pajak dibandingkan dengan dividen. 


\section{Indikator Kebijakan Dividen}

\section{Dividend Yield}

Dividend Yield menunjukan seberapa besar suatu perusahaan membagikan dividend kepada pemilik saham dilihat dari harga sahamnya yang sekarang.

\section{Dividend Payout Ratio}

Dividend Payout Ratio menunjukkan persentase laba perusahaan yang dibayarkan kepada pemegang saham secara tuna

\section{Pengertian Dividend Payout Ratio}

Dividend Payout Ratio merupakan salah satu indikator dari kebijakan dividen.Menurut Horne dan Wachowicz (2012:270), Dividend Payout Ratio adalah dividen tunai tahunan yang dibagi dengan laba tahunan, atau dividen per lembar saham dibagi dengan laba per lembar saham. Rasio tersebut menunjukkan persentase laba perusahaan yang dibayarkan kepada pemegang saham secara tunai.

\section{Faktor Yang Mempengaruhi Kebijakan Dividen}

1. Keputusan Rapat Umum Pemegang Saham (RUPS)

Rapat Umum Pemegang Saham merupakan wadah para pemegang saham untuk mengambil keputusan penting yang berkaitan dengan modal yang ditanam dalam perusahaan, dengan memperhatikan ketentuan Anggaran Dasar dan peraturan perundang-undangan. Menurut Noventri Musthikawati (2010), keputusan yang diambil dalam RUPS didasari pada kepentingan usaha Perseroan dalam jangka panjang. Salah satu keputusan yang ditentukan dalam RUPS adalah tentang pembagian laba.

2. Cash Position (CP)

Posisi kas dari suatu perusahaan merupakan faktor penting yang harus dipertimbangkan sebelum mengambil keputusan penetapan besarnya dividen yang akan dibayarkan kepada para pemegang saham, oleh karena dividen merupakan cash outflow, maka kesimpulan yang dapat diambil yaitu makin kuatnya CP berarti makin besar kemampuannya membayar dividen, sehingga $\mathrm{CP}$ memiliki hubungan positif terhadap Dividend Payout Ratio.

2. Debt to Equity Ratio (DER)

Menurut Horne dan Wachowicz (2012:235) DER dapat dihitung dengan membandingkan total hutang perusahaan dengan ekuitas pemegang saham. Jadi jika DER mengalami kenaikan maka total hutang yang dimiliki perusahaan juga ikut naik, jika total hutang naik akan berpotensi beban bunga yang ditanggung perusahaan juga akan mengalami kenaikan hal ini berpotensi pembayaran dividen kepada para pemegang saham akan mengalami penurunan.

3. Return On Assets (ROA)

Menurut Horne dan Wachowicz (2012:235) ROA dapat dihitung dengan membandingkan laba bersih setelah pajak dengan total aktiva. Berdasarkan teori tersebut dapat dinyatakan bahwa semakin tinggi ROA menunjukkan kinerja perusahaan semakin baik,artinya ROA memiliki hubungan positif terhadap Dividend Payout Ratio.

4. Earning per Share (EPS)

Menurut Horne dan Wachowicz (2012:5) EPS dapat dirumuskan dengan laba setelah pajak (EAT) di bagi dengan jumlah saham biasa yang beredar.Jadi semakin tinggi nilai EPS menunjukkan semakin besar laba yang diperoleh perusahaan, Semakin besar EPS maka semakin tinggi dividen yang dibagikan, sehingga EPS memiliki hubungan positif dengan Dividend Payout Ratio. 


\section{Gross Profit Margin}

Gross Profit Margin merupakan salah satu rasio dari profitabilitas yang menunjukkan kemampuan perusahaan dalam menghasilkan laba kotor dari transaksi penjualanya.Gross Profit Margin yangtinggi mengindikasikan bahwa total penjualan perusahaan juga tinggi, jika penjualan tinggi maka berpotensi laba yang diperoleh perusahaan juga semakin tinggi sehingga potensi pembayaran dividen kepada pemegang saham juga semakin tinggi.

6. Net Profit Margin (NPM)

Net Profit Margin merupakan salah satu dari rasio profitabilitas yang menunjukkan keberhasilan perusahaan didalam menghasilkan keuntungan, dimana mengukur tingkat kembalian keuntungan bersih terhadap penjualan bersihnya. Net Profit Margin yang tinggi menandakan kemampuan perusahaan menghasilkan laba yang tinggi dari hasil penjualannya. Jika laba tinggi potensi pembagian dividen kepada pemegang saham juga akan tinggi.

7. Return on Equity (ROE)

Return On Equity (ROE) merupakan salah satu rasio dari profitabilitas yang menunjukkan kemampuan perusahaan dalam menghasilkan laba dari total ekuitas yang dimiliki perusahaan. ROE yang tinggi menandakan kemampuan perusahaan menghasilkan laba yang tinggi dari total ekuitas yang ada di perusahaan. Jika laba tinggi potensi pembagian dividen kepada pemegang saham juga akan tinggi.

8. Current Ratio

Current Ratio merupakan salah satu indikator dari rasio likuiditas.Current Ratio merupakan kemampuan perusahaan dalam memenuhi kewajiban jangka pendek perusahaan dengan total aktiva lancar yang ada di perusahaan

\section{Berdasarkan penjelasan diatas maka kerangka pemikiran teoritis dapat digambarkan seperti dibawah ini :}

\section{Gambar 1}

Kerangka Pemikiran

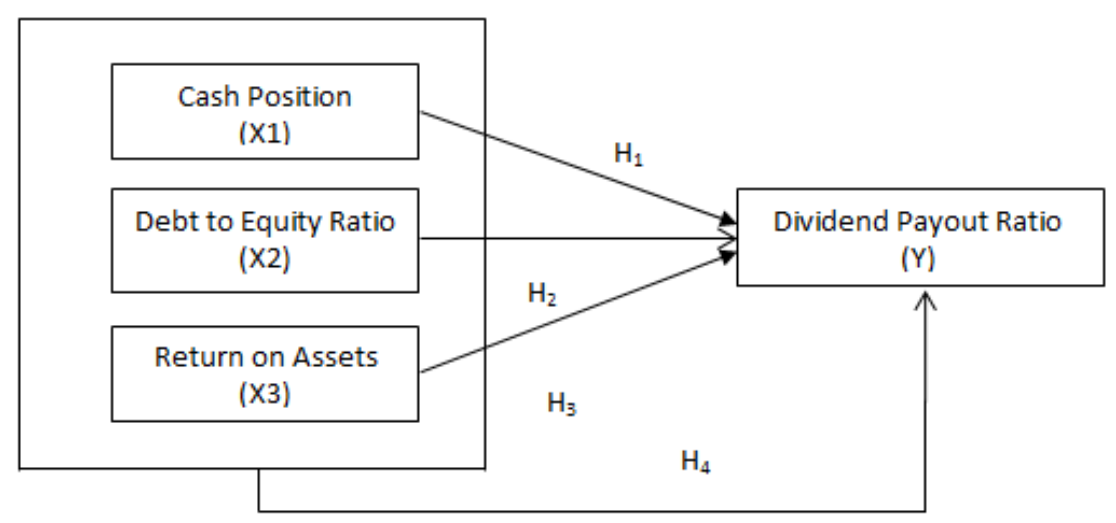

Sumber : Diolah Penulis 


\section{METODE}

\section{Populasi dan Sampel}

Populasi yang akan menjadi objek dalam penelitian ini adalah perusahaan manufaktur yang terdaftar di BEI periode 2013 - 2015. Adapun teknik pengambilan sampling yang digunakan adalah purposive sampling, yaitu pemilihan anggota sampel dengan mendasarkan pada kriteria - kriteria tertentu. Kriteria yang digunakan dalam penelitian ini: a) Perusahaan manufaktur yang terdaftar di Bursa Efek Indonesia (BEI) periode 2013-2015. b) Perusahaan manufaktur yang memiliki data dan laporan keuangan yang lengkap selama 2013-2015. Berdasarkan kriteria yang telah ditentukan maka sampel yang termasuk dalam penelitian ini dilihat dalam tabel berikut :

Tabel 3

Tahapan Seleksi Sampel Dengan Kriteria

\begin{tabular}{|l|c|}
\hline \multicolumn{1}{|c|}{ Kriteria Sampel } & Jumlah Perusahaan \\
\hline $\begin{array}{l}\text { Jumlah perusahaan manufaktur yang } \\
\text { terdaftar di Bursa Efek Indonesia 2013-2015 }\end{array}$ & 420 \\
\hline $\begin{array}{l}\text { Jumlah perusahaan manufaktur yang tidak } \\
\text { memiliki laporan keuangan dan data yang } \\
\text { lengkap untuk penelitian }\end{array}$ & 287 \\
\hline $\begin{array}{l}\text { Total Perusahaan manufaktur yang menjadi } \\
\text { populasi penelitian }\end{array}$ & 133 \\
\hline
\end{tabular}

Sumber : Diolah Penulis

Kriteria diatas dibuat untuk menghasilkan sampel yang dapat mewakili kondisi populasi yang sebenarnya. Selain itu, pengolahan data dalam penelitian ini menggunakan analisis regresi berganda sehingga seluruh data harus melewati uji normalitas data. Dengan demikian dalam penelitian ini digunakan 133 observasi, tetapi dari seluruh observasi ini 90 observasi dikeluarkan dari pengamatan karena ada data yang memiliki nilai terlalu tinggi atau terlalu rendah (ekstrim) sehingga total observasi dalam penelitian ini berjumlah 43 observasi.

\section{Desain Penelitian}

Jenis penelitian ini adalah penelitian kausal yaitu penelitian untuk mengetahui pengaruh satu atau lebih variabel bebas (independent variable) terhadap variabel terikat (dependent variable).

\section{Definisi Operasional Variabel dan Skala Pengukuran Variabel Independen}

Variabel bebas (Independent Variable) adalah variabel yang menentukan atau yang mempengaruhi adanya variabel yang lain (X). Variabel bebas yang digunakan dalam penelitian ini berupa: 
1. Cash Position

Cash position atau posisi kas merupakan rasio saldo akhir tahun dengan earning after tax. Faktor ini merupakan faktor internal yang dapat dikendalikan oleh manajemen, sehingga pengaruhnya dapat dirasakan secara langsung bagi kebijakan dividen. Dividen merupakan cash outflow dengan demikian makin kuatnya posisi kas perusahaan akansemakin besar kemampuan untuk membayar dividen. Berikut rumus dari Cash Position:

\section{Rumus Cash Position}

$$
\mathrm{CP}=\frac{\text { Saldo Kas Akhir }}{\text { Laba Bersih Setelah Pajak }}
$$

2. Debt to Equity Ratio

Debt to equity ratio (DER) mencerminkan kemampuan perusahaan dalam memenuhi seluruh kewajibannya, yang ditunjukkan oleh beberapa bagian modal sendiri yang digunakan untuk membayar hutang. Berikut rumus dari Debt to Equity Ratio:

\section{Rumus Debt to Equity Ratio}

$$
\text { DER }=\frac{\text { Total Hutang }}{\text { Total Modal Sendiri }}
$$

3. Return on Assets

Return on assets merupakan perbandingan antara earning after tax dengan total asset. Dengan profitabilitas sebagai ukurannya, yaitu tingkat keuntungan bersih yang mampu diraih oleh perusahaan pada saat menjalankan operasinya. ROA dapat dihitung dengan menggunakan rumus sebagai berikut :

Rumus Return on Assets

$$
\mathrm{ROA}=\frac{\text { Laba Bersih Setelah Pajak }}{\text { Total Aset }}
$$

\section{Variabel Dependen}

Variabel Dependen adalah variabel yang diduga sebagai akibat atau variabel yang dipengaruhi oleh variabel yang mendahuluinya, yakni variabel bebas (variabel Independen).Variabel Dependen (Y) dalam penelitian ini adalah dividend payout ratio. Berikut rumus dari Dividen Payout Ratio: 


\section{Rumus Dividen Payout Ratio}

\begin{tabular}{|c|c|c|c|}
\hline \multirow{2}{*}{$\mathrm{DPR}=$} & DPS & \multirow{2}{*}{$\mathrm{EPS}=$} & Laba Bersih \\
\hline & EPS & & $\begin{array}{c}\text { Jumlah Saham yang } \\
\text { Beredar }\end{array}$ \\
\hline
\end{tabular}

Keterangan:

DPR = Dividend Payout Ratio

DPS $=$ Dividen Per Lembar Saham

EPS = Laba Per Lembar Saham

\section{Skala Pengukuran}

Skala pengukuran yang digunaka pada variabel Independen dan variabel Dependen menggunakan skala ratio.

\section{Metode Analisa Data}

a. Analisis Deskriptif

Metode analisis deskriptif merupakan metode yang digunakan untuk menganalisis data-data yang tersedia dan diolah sehingga diperoleh gambaran yang jelas mengenai fakta-fakta dan hubungan antara fenomena yang diteliti.

Analisis Statistik

1. Uji Asumsi Klasik

a) Uji Normalitas

Uji normalitas bertujuan untuk menguji apakah data berdistribusi normal.Model regresi yang baik ialah yang memiliki distribusi data normal atau mendekati normal. Ada dua cara untuk mengetahui apakah data berdistribusi normal atau tidak, yaitu dengan cara analisis grafik dan uji statistik. Selain itu juga dilakukan dengan uji statistik Kolmogorov-Smirnov (Uji K-S).Data yang berdistribusi normal ditandai dengan asymp. Sig (2-tailed) > 0,05 (Ghozali Imam, 2011).

b) Uji Multikolinieritas

Uji multikolinieritas ini bertujuan untuk menguji apakah model regresi ditemukan adanya hubungan antara variabel bebas.Model regresi yang baik seharusnya tidak terjadi korelasi diantara variabel independen.

c) Uji Heteroskedastisitas

Uji hesteroskedastisitas digunakan untuk menguji apakah dalam sebuah model regresi terjadi ketidaksamaan varians dari residual pada setiap pengamatan. Jika dalam varians dari residual satu pengamatan ke pengamatan lain tetap, maka disebut homokedastisitas dan jika berbeda disebut heteroskedastisitas. Uji heteroskedatisitas dalam penelitian ini menggunakan uji glejser yaitu meregresikan nilai absolute residual terhadap variabel independen.Hal ini terlihat dari probabilitas signifikansinya di atas tingkat kepercayaan 5\%.Jadi dapat disimpulkan model regresi tidak mengandung adanya heterokedatisitas (Ghozali Imam, 2011). 
d) Uji Autokorelasi

Uji ini bertujuan untuk menguji apakah dalam model regresi linier ada korelasi antara kesalahan penganggu pada periode $t$ dengan kesalahan pengganggu pada periode t-1 (sebelumnya).Pengujian ada tidaknya autokolerasi dalam persamaan ini digunakan uji Durbin Watson (DW - Test).Model regresi yang baik adalah model yang tidak mengandung autokolerasi.

\section{Analisis Regresi Linear Berganda}

Metode analisis regresi linear berganda merupakan suatu bentuk hubungan linear antara dua atau lebih variabel independen dengan variabel dependennya.

a) Persamaan regresi berganda

Model ini digunakan untuk mengetahui pengaruh variabel bebas terhadap variabel terikat dengan persamaan sebagai berikut:

$\mathrm{Y}=\mathrm{a}+\mathrm{b}_{1} \mathrm{X}_{1}+\mathrm{b}_{2} \mathrm{X}_{2}+\mathrm{b}_{3} \mathrm{X}_{3}+\mathrm{e}$

Keterangan:

$\mathrm{Y}=$ dividen payout ratio

$\mathrm{a}=$ konstanta

$\mathrm{b}=$ koefisien regresi

$\mathrm{X}_{1}=$ cash position

$\mathrm{X}_{2}=$ debt to equity ratio

$\mathrm{X}_{3}=$ return on Assets

$\mathrm{e}=$ error

b) Uji F

Uji F pada dasarnya menunjukkan apakah semua variabel independen yang dimasukkan dalam model mempunyai pengaruh secara bersama sama terhadap variabel dependennya (Ghozali Imam, 2011).

c) Uji t

Uji t pada dasarnya menunjukkan seberapa jauh pengaruh satu variabel independen secara individual dalam menerangkan variasi variabel dependen (Ghozali Imam, 2011).

\section{PEMBAHASAN}

\section{Hasil Uji F}

Uji F (Uji Simultan) dilakukan untuk melihat pengaruh variabel independen secara simultan terhadap variabel dependen.Untuk melihat hasil pengujian dapat dilihat pada tabel Anova. Berikut adalah hasil dari nilai $\mathrm{F}$ hitung dan signifikansi untuk penelitian ini :

\section{Tabel 4}

Uji Simultan (Uji F)

ANOVA $^{\mathrm{a}}$

\begin{tabular}{|ll|r|r|r|r|r|}
\hline \multicolumn{2}{|l|}{ Model } & $\begin{array}{c}\text { Sum of } \\
\text { Squares }\end{array}$ & Df & Mean Square & F & Sig. \\
\hline 1 & Regression & 2478.326 & 3 & 826.109 & 3.392 & $.027^{\mathrm{b}}$ \\
& Residual & 9498.351 & 39 & 243.547 & & \\
& Total & 11976.677 & 42 & & & \\
\hline
\end{tabular}

a. Dependent Variable: DPR

b. Predictors: (Constant), ROA, CP, DER

Sumber: Output SPSS 
Hasil pengujian uji $\mathrm{F}$ menunjukkan nilai signifikan yang diperoleh adalah 0,027. Karena nilai sig. lebih kecil dari 0,05 maka $\mathrm{H}_{0}$ ditolak dan $\mathrm{H}_{1}$ diterima sehingga dapat disimpulkan bahwa variabel Cash Position, Debt To Equity Ratio dan Return On Assets secara simultan berpengaruh terhadap variabel Dividend Payout Ratio pada perusahaan manufaktur yang terdaftar di BEI periode 2013-2015.

\section{Hasil Uji t}

Uji t dilakukan untuk mengetahui apakah secara individu (parsial) variabel independen mempengaruhi variabel dependen secara signifikan atau tidak. Berikut ini adalah hasil perhitungan nilai t hitung dan taraf signifikannya dalam penelitian ini :

Tabel 5

Uji Parsial (Uji t)

Coefficients $^{\mathrm{a}}$

\begin{tabular}{|c|c|c|c|c|c|}
\hline \multirow[b]{2}{*}{ Model } & \multicolumn{2}{|c|}{$\begin{array}{l}\text { Unstandardized } \\
\text { Coefficients }\end{array}$} & \multirow{2}{*}{$\begin{array}{c}\begin{array}{c}\text { Standardiz } \\
\text { ed } \\
\text { Coefficient } \\
\text { s }\end{array} \\
\text { Beta }\end{array}$} & & \multirow[b]{2}{*}{ Sig. } \\
\hline & B & $\begin{array}{l}\text { Std. } \\
\text { Error }\end{array}$ & & & \\
\hline 1 (Constant) & 44.152 & 11.764 & & 3.753 & .001 \\
\hline $\mathrm{CP}$ & -1.595 & 5.483 & -.042 & -.291 & .773 \\
\hline DER & 18.337 & 8.402 & -.372 & $2.182^{-}$ & .035 \\
\hline ROA & .428 & .605 & .121 & .707 & .484 \\
\hline
\end{tabular}

a. Dependent Variable: DPR

Sumber : Output SPSS

Hasil pengujian uji $\mathrm{t}$ menunjukkan nilai signifikansi untuk setiap variabel independen. Dari hasil pengujian 3 variabel independen dapat diketahui bahwa Cash Position dan Return On Assets mempunyai nilai signifikansi lebih besar dari 0,05 sehingga Ho diterima, artinya Cash Position dan Return On Assets tidak berpengaruh terhadap Dividend Payout Ratio. Sedangkan Debt To Equity Ratio mempunyai nilai signifikansi sebesar 0,035, nilai ini lebih kecil dari 0,05 sehingga Ho ditolak, artinya Debt To Equity Ratio berpengaruh terhadap Dividend Payout Ratio.

Untuk mengetahui besar pengaruh variabel Independen secara simultan berpengaruh terhadap variabel terikat dengan melihat nilai Adjusted $R$-Square pada tabel Model Summary berikut ini. 
Tabel 6

R-Square

Model Summary ${ }^{\text {b }}$

\begin{tabular}{|c|c|c|c|c|c|c|c|c|c|c|}
\hline \multirow[b]{2}{*}{$\begin{array}{l}\text { Mode } \\
1\end{array}$} & & \multirow[b]{2}{*}{$\begin{array}{c}\mathrm{R} \\
\text { Square }\end{array}$} & \multirow[b]{2}{*}{$\begin{array}{c}\text { Adjusted } \\
\text { R } \\
\text { Square } \\
\end{array}$} & \multirow{2}{*}{$\begin{array}{c}\text { Std. } \\
\text { Error of } \\
\text { the } \\
\text { Estimate }\end{array}$} & \multicolumn{5}{|c|}{ Change Statistics } & \multirow{2}{*}{$\begin{array}{c}\text { Durbin } \\
- \\
\text { Watso } \\
n \\
\end{array}$} \\
\hline & & & & & $\begin{array}{c}\mathrm{R} \\
\text { Square } \\
\text { Change }\end{array}$ & $\begin{array}{c}\mathrm{F} \\
\text { Chang } \\
\mathrm{e}\end{array}$ & $\begin{array}{c}\mathrm{df} \\
1\end{array}$ & $\begin{array}{c}\mathrm{df} \\
2\end{array}$ & $\begin{array}{c}\text { Sig. F } \\
\text { Change }\end{array}$ & \\
\hline 1 & $.455^{\mathrm{a}}$ & .207 & .146 & $\begin{array}{r}15.6060 \\
1\end{array}$ & .207 & 3.392 & 3 & 39 & .027 & 1.800 \\
\hline
\end{tabular}

a. Predictors: (Constant), ROA, CP, DER

b. Dependent Variable: DPR

Sumber : Output SPSS

Dari tabel diatas menunjukkan bahwa 20,7 \% dari variabel perubahan Dividend Payout Ratio dapat dijelaskan oleh variabel independennya. Sementara sisanya 79,3\% dapat dijelaskan oleh variabel lainya diluar variabel yang di teliti.

\section{Persamaan Regresi}

Berdasarkan hasil tabel Coefficients tersebut, dapat disusun persamaan regresi linier berganda sebagai berikut :

\section{Tabel 7}

\section{Tabel Persamaan Regresi}

\section{Coefficients $^{\mathrm{a}}$}

\begin{tabular}{|c|c|c|c|c|c|c|c|}
\hline \multirow[b]{2}{*}{ Model } & \multicolumn{2}{|c|}{$\begin{array}{c}\text { Unstandardized } \\
\text { Coefficients }\end{array}$} & \multirow{2}{*}{$\begin{array}{c}\text { Standardize } \\
\mathrm{d} \\
\text { Coefficient } \\
\mathrm{s}\end{array}$} & \multirow[b]{2}{*}{$\mathrm{T}$} & \multirow[b]{2}{*}{ Sig. } & \multicolumn{2}{|c|}{$\begin{array}{c}\text { Collinearity } \\
\text { Statistics }\end{array}$} \\
\hline & B & $\begin{array}{l}\text { Std. } \\
\text { Error }\end{array}$ & & & & $\begin{array}{c}\text { Toleranc } \\
\mathrm{e}\end{array}$ & VIF \\
\hline (Constant) & 44.152 & 11.764 & & 3.753 & .001 & & \\
\hline $\mathrm{CP}$ & -1.595 & 5.483 & -.042 & -.291 & .773 & .986 & 1.014 \\
\hline DER & $18.337^{-}$ & 8.402 & -.372 & $2.182^{-}$ & .035 & .701 & 1.426 \\
\hline ROA & .428 & .605 & .121 & .707 & .484 & .696 & 1.438 \\
\hline
\end{tabular}

a. Dependent Variable: DPR

Sumber : Output SPSS

$$
Y=44,152-1,595 X_{1}-18,337 X_{2}+0,428 X_{3}
$$

Persamaan tersebut mempunyai interprestasi sebagai berikut :

Konstanta $=44,152$, Jika nilai variabel Cash Position $\left(\mathrm{X}_{1}\right)$, Debt To Equity Ratio $\left(\mathrm{X}_{2}\right)$, dan Return On Assets $\left(\mathrm{X}_{3}\right)$ dianggap sama dengan nol yang artinya tidak diperhitungkan, maka 
nilai variabel Dividend Payout Ratio (Y) sebesar 44,152. Jika variabel Debt To Equity Ratio $\left(\mathrm{X}_{2}\right)$ mengalami kenaikan sebesar satu satuan, sementara Cash Position $\left(\mathrm{X}_{1}\right)$ dan Return On assets $\left(\mathrm{X}_{3}\right)$ dianggap tetap, maka akan mempengaruhi penurunan nilai variabel Dividend Payout Ratio (Y) sebesar - 18,337.

Perbandingan hasil penelitian dengan teori

1. Pengaruh Cash Position ( $\left.\mathrm{X}_{1}\right)$ terhadap Dividend Payout Ratio (Y) pada Perusahaan Manufaktur yang terdaftardi BEI Periode 2013-2015.

Semakin tinggi Cash Position menunjukkan uang kas yang tersedia dalam perusahaan juga semakin tinggi. Semakin tinggi uang kas perusahaan maka menunjukkan semakin tinggi juga kemampuan perusahaan mampu dalam membayarkan dividen kepada para investor. Hasil penelitian menunjukkan bahwa variabel Cash Position tidak berpengaruh terhadap Dividen Payout Ratio pada perusahaan manufaktur yang terdaftar di BEI periode 2013-2015, hal ini berarti tidak sesuai dengan teori yang menyatakan bahwa Cash Position berpengaruh terhadap Dividend Payout Ratio.Kemungkinan dikarenakan sampel penelitian lebih kecil daripada rata-rata populasi sesungguhnya.Nilai rata-rata populasi Cash Position adalah 2,1744 sementara nilai rata-rata sampel penelitian hanya sebesar 0.9314 .

2. Pengaruh Debt To Equity Ratio ( $\left.\mathrm{X}_{2}\right)$ terhadap Dividend Payout Ratio (Y) pada perusahaan Manufaktur yang terdaftar di BEI periode 2013-2015.

Hasil penelitian menunjukkan bahwa variabel Debt To Equity Ratio berpengaruh terhadap Dividen Payout Ratiopada perusahaan manufaktur yang terdaftar di BEI periode 2013-2015. Hal ini sesuai dengan teori yang menyatakan bahwa Debt To Equity Ratio berpengaruh terhadapDividend Payout Ratio.

3. Pengaruh Return On Assets ( $\mathbf{X}_{3}$ ) terhadap Dividend Payout Ratio (Y) pada perusahaan Manufaktur yang terdatfar di BEI periode 2013-2015.

Hasil penelitian ini dapat disimpulkan bahwa tidak terdapat pengaruh antara Return On Assets dengan Dividend Payout Ratio pada perusahaan manufaktur yang terdaftar di BEI periode 2013-2015.Hal ini berarti tidak sesuai dengan teori yang menyatakan bahwa Return on assets berpengaruh terhadap Dividend Payout Ratio.

4. Pengaruh Cash Position, Debt To Equity Ratio, dan Return On Assets terhadap Dividend Payout Ratio Pada Perusahaan Manufaktur yang terdaftar di BEI periode 2013-2015

Hasil penelitian menunjukkan secara simultan variabel Cash Position, Debt To Equity Ratio, dan Return On Assets berpengaruh terhadap Dividend Payout Ratio Pada Perusahaan manufaktur yang terdaftar di BEI periode 2013-2015

\section{Perbandingan Hasil Penelitian dengan Penelitian Sebelumnya}

Hasil penelitian ini kemudian dibandingkan dengan penelitian sebelumnya yang relevan yang telah disebutkan sebelumnya. Berikut hasil perbandingan dari hasil penelitian dengan penelitian sebelumnya : 
Tabel 8

Perbandingan Hasil Penelitian

\begin{tabular}{|c|l|l|l|}
\hline No & \multicolumn{1}{|c|}{ Hasil Penelitian } & \multicolumn{1}{|c|}{ Penelitian Sebelumnya } \\
\hline 1 & \multicolumn{1}{|c|}{$\begin{array}{c}\text { Konsisten } \\
\text { CP tidak berpengaruh } \\
\text { terhadap DPR }\end{array}$} & $\begin{array}{l}\text { 1. Esti Rudiana(2016) } \\
\text { 2. Gede Agus (2014) }\end{array}$ & $\begin{array}{l}\text { 1.Siti Nurjanah (2013) } \\
\text { 2.Azhari (2012) }\end{array}$ \\
\hline 2 & $\begin{array}{l}\text { DER berpengaruh } \\
\text { terhadap DPR }\end{array}$ & 1. Gede Agus (2014) & $\begin{array}{l}\text { 1. Siti Nurjanah } \\
(2013)\end{array}$ \\
& & & $\begin{array}{l}\text { 2. Esti } \\
\text { Rudiana(2016) }\end{array}$ \\
\hline 3 & $\begin{array}{l}\text { ROAtidak berpengaruh } \\
\text { terhadap DPR }\end{array}$ & 1. Esti Rudiana(2016) & $\begin{array}{l}\text { 1. Fenny Pramita } \\
\text { (2013) }\end{array}$ \\
\hline 4 & $\begin{array}{l}\text { CP, DER dan ROA } \\
\text { secara simultan } \\
\text { berpengaruh terhadap }\end{array}$ & $\begin{array}{l}\text { 1. Azhari (2012) } \\
\text { 2. Fenny Pramita (2013) } \\
\text { 3. Siti Nurjanah (2013) } \\
\text { 4. Gede Agus (2014) }\end{array}$ & \\
& 5. Esti Rudiana (2016) & \\
\hline
\end{tabular}

Sumber :Data Diolah Peneliti

\section{PENUTUP}

Berdasarkan hasil penelitian dapat disimpulkan: 1).Variable Cash Position tidak berpengaruh terhadap Dividend Payout Ratio pada perusahaan manufaktur yang terdaftar di BEI periode 2013-2015. 2).Variable Debt ToEquity Ratio berpengaruh terhadap Dividend Payout Ratio pada perusahaan manufaktur yang terdaftar di BEI periode 20132015. 3). Variable Return On Asstes tidak berpengaruh terhadap Dividend Payout Ratio pada perusahaan manufaktur yang terdaftar di BEI periode 2013-2015. 4). Variable Cash Position, Debt To Equity Ratio, dan Return On Assets secara simultan berpengaruh terhadap Dividend Payout Ratio pada perusahaan manufaktur yang terdaftar di BEI periode 2013-2015.

Berdasarkan penelitian yang telah dilakukan, peneliti menyarankan beberapa hal untuk penelitian selanjutnya yaitu :1) Populasi dalam penelitian ini adalah perusahaan manufaktur yang terdaftar di BEI periode 2013-2015. Hal ini mungkin akan berbeda jika dilakukan pada perusahaan lain dan pada periode yang lebih panjang. Saran untuk peneliti selanjutnya adalah perlu mempertimbangkan populasi lain serta periode penelitian yang harus ditambah lebih panjang untuk mendapatkan hasil yang lebih meyakinkan, sehingga dapat digunakan untuk analisa jangka panjang. 2) Untuk peneliti selanjutnya perlu menggunakan variabel lain agar mengetahui variabel apa yang sebenarnya mempengaruhi Dividend Payout Ratio. 


\section{DAFTAR PUSTAKA}

Azhari. 2012. "Pengaruh Cash Position terhadap Dividen Payout Rasio pada Perusahaan Asuransi yang Listing di Bursa Efek Indonesia".

Azwar Syarifuddin. 2013. Metode Penelitian. Yogyakarta: Pustaka Pelajar.

Bambang Sumardjoko. 2011. Metode Statistik. Jakarta: Badan Penerbit-FKIP UMS

Brigham, Eugene F., dan Joel F. Houston, 2012. Dasar-dasar Manajemen Keuangan.Jakarta : Salemba Empat.

Van Horne, James C dan John M. Wachowicz. 2012. Prinsip-Prinsip Manajemen Keuangan. Jakarta: Salemba Empat.

Esti Rudiana. 2016. "Pengaruh Cash Position, Debt Equty Ratio, Retrun on Asset, Current Ratio, Firm Size, Price Earning Ratio, dan Total Assets Turn Over Terhadap Dividend Payout Ratio Pada Perusahaan Manufaktur Periode 2007-2014".

Fahmi, Irham. 2012. Analisis Laporan Keuangan. Cetakan Ke-. Bandung: Alfabeta

Fahmi, Irham, dan Hadi. 2011. Teori Portofolio dan Analisis Investasi. Edisi Kedua. Bandung: Alfabeta

Fenny Pramita. 2013. "Pengaruh Cash Ratio, ROA, dan Growth of Company Terhadap Dividend Payout Ratio".

Gede Agus Mahaputra dan Ni Gusti Putu Wirawati. 2014. "Pengaruh Faktor Keuangan dan Ukuran Perusahaan Pada Dividend Payout Ratio Perusahaan Perbankan".

Ghozali Imam.2011, Aplikasi Analisis Multivariate dengan Program SPSS, Badan Penerbit Universitas Diponegoro.

Gumanti, Tatang. 2011. Manajemen Investasi : Konsep, Teori, dan Aplikasi. Edisi Pertama. Jakarta : Mitra Wacana Media.

Martalena dan Maya Malinda. 2011. Pengantar Pasar Modal. Bandung : Andi Yogyakarta.

Mustikawati, Noventri. 2010. Faktor-faktor yang mempengaruhi rasio pembayaran dividen

(Studi pada Perusahaan yang Terdaftardi BEI tahun 2005-2008). Skripsi FE manajemen, Universitas Sebelas Maret Surakarta.

Rudianto. 2012. Pengantar Akuntansi Adaptasi IFRS. Jakarta, Erlangga.

Sedarmayanti dan Hidayat, Syarifudin. 2011. Metodologi Penelitian. Bandung: Mandar Maju Singgih Santoso. 2014. Panduan Lengkap SPSS Versi 20 Edisi Revisi. Jakarta: Gramedia.

Siti Nurjanah Kuniawan, Rina Arifati dan Rita Andini. 2013 "Analisi Pengaruh Cash Position, Debt to Equity Ratio, dan Return on Equity Terhadap Dividend Payout Ratio Pada PEerusahaan Manufaktur di Bursa Efek Indonesia pada Periode 2009 2011 ".

Sugiono. 2011. Metode Penelitian Kuantitatif, Kualitatif dan R\&D. Bandung: ALFABETA

Sunariyah.2011. Pengantar Pengetahuan Pasar Modal. Edisi Keenam. Yogyakarta: UPP STIM YKPN.

Sutrisno. 2012. Manajemen Keuangan Teori, Konsep dan Aplikasi. Yogyakarta: Ekonisia 